\section{ENERGY IN THE SERVICE OF MAN EXHIBITION AT BIRMINGHAM}

$\mathrm{I}_{\mathrm{B}}^{\mathrm{N}}$ connexion with the annual meeting of the British Association an exhibition has been arranged at the University of Birmingham to illustrate the topic "Energy in the Service of Man" suggested by Unesco for world-wide discussion and study in 1950. The exhibition has been sponsored by the National Coal Board, the Gas Council and the British Electricity Authority in conjunction with the Birmingham City Museum and Art Gallery and the Birmingham Common Good Trust, and is staged in the Mechanical Engineering Department of the University at Edgbaston. It was open to the public during August 21-29 and will be open again during September 7-9 after members of the British Association have had the opportunity of visiting it during the period of the meeting.

It is fitting that such an exhibition should be held in Birmingham, which owes its rapid development to the early exploitation of industrial power following the inventions of that small group of men who made the industrial revolution possible. The first section of the exhibition pays tribute to the work of these inventors, many of whom had close connexions with Birmingham ; drawings, letters and memoranda from the Boulton and Watt collection are on display, with William Murdock's note-book and a calculation book of James Watt, alongside working models of early steam engines. The original engine constructed by Murdock in 1784 and the first electroplating machine patented in $\mathbf{1 8 4 2}$ by John Stephen Woolrich, a Birmingham chemist, are notable exhibits.

Coal is the main source of energy in Great Britain, and the formation of a coalfield from forest debris is illustrated in a series of coloured plates showing various stages in the process. A selection of fossil remains of Coal Measure plants accompanies this exhibit.

The development of mining methods during the past two hundred and fifty years is shown by a series of diagrams and models. The horse whim and various types of gin used for raising coal before the invention of steam engines contrast markediy with modern examples of mechanization, and the hazardous nature of early mining operations is exemplified by a model demonstrating a method of setting off underground gas accumulations by the use of a naked flame. Sectional models illustrate the principles of 'room and pillar' and of 'Iongwall' methods of mining, and new developments in coal cutting are represented by working models of the hydraulically operated Samson stripper, which shears off the coal face and ploughs it on to a conveyor as it advances, and by the Meco-Moore cutter loader. A full-scale modern coal cutter is shown working along a portion of a longwall face.

Coal coming from the pit contains shale and other impurities, and as thinner and deeper seams are mined, and as mechanization increases, so does the amount of dirt. Coal cleaning thus becomes of great importance, and the principles of a dense-medium coal-washing plant are indicated by a model in which the coal is shown floating in a medium of specific gravity greater than that of coal but less than that of the dirt, which sinks and is removed.

Coal utilization is excellently portrayed, and a number of diagrams show the numerous by-products of coal carbonization. Sectional diagrams of a typical combination underjet coke oven and of a modern continuous vertical-retort setting indicate the principal methods of high-temperature carbonization employed at the present time; flow diagrams and a working model of a gasworks provide further information. The extraction of benzole from coal gas as practised in the gas industry is described by an attractive flow diagram, and the cycle of operations of an automatic carburetted water-gas plant is realistically reproduced by another model.

The downjet-combustion of coke is described and methods of testing this solid fuel are shown.

Refractory materials are widely employed in the gas industry, and a series of well-chosen exhibits show methods of testing these materials and their deterioration in use.

The removal of tar fog from coal-gas by electrodetarrers is now a common procedure at gasworks. This process resulted directly from the work of Sir Oliver Lodge (the first principal of the University of Birmingham) and of Dr. F. G. Cottrell in the United States, and an effective demonstration of electrical precipitation is included in the exhibition.

A series of photographs illustrates recent investigations by the Gas Research Board and the use of modern scientific instruments in the gas industry.

Waste-heat recovery is a topic of considerable interest to the gas engineer, for the flue gases leave retort settings at about $900^{\circ} \mathrm{C}$, and by passing these through waste-heat boilers a considerable saving in fuel can be effected. As an alternative procedure, a $700-\mathrm{kW}$. closed-cycle gas turbine is to be installed at a West Midlands gas works; a model of this unit is displayed at the exhibition.

A selection of modern gas burners and an illustration of gas distribution methods complete the gas section.

The British Electricity Authority is at present building thirty-eight new power stations and installing new plant at forty three existing ones. The generation of electric power and new developments are illustrated at the exhibition by a number of wellchosen models and demonstrations, including sectional models of the generating station at Staythorpe and of a typical hydrogen-cooled turbo-alternator. A particularly interesting exhibit is a model of the Metropolitan-Vickers $15,000-\mathrm{kW}$. gas turbo-alternator designed for the Trafford Park station of the British Electricity Authority.

Water cooling presents a considerable problem at power stations, and working models of cooling towers are on view.

The recovery of a valuable element from a waste product is depicted in this section of the exhibition. It has been known for a number of years that the flue-dusts from boilers and gas producers contain small amounts of germanium, gallium and other rare elements, and it has been found that certain coals from the Northumberland and Durham coalfield yield up to 0.001 per cent of germanium. The extraction of this element is now undertaken commercially from flue-dust because of its valuable properties as a semi-conductor. Germanium diodes and triodes are displayed alongside samples from various stages in the extraction of the element.

A novel exhibit is the fuel cell constructed by the British Coal Utilization Research Association. The prospect of developing electrical energy directly has for long attracted the attention of investigators, but no fuel cell has yet proved completely successful. 
Demonstrations of electrolytic polishing and of tests on a television receiver lend interest to this section, and further exhibits deal with the transmission of electric power and its use in the electric arc furnace employed in alloy steel manufacture.

The visitor leaving the exhibition is faced by a small pellet of uranium with an accompanying notice which reminds him that quick results should not be expected from work now in progress directed towards the use of atomic energy for power production. Design studies and cost estimates for nuclear reactors will necessarily take a number of years to complete, before plans for full-scale nuclear power producers can be made.

In connexion with the exhibition, five public lectures have been delivered at the Midland Institute,
Birmingham, by Mr. W. V. C. Gale, Mr. James R. Beard, Dr. A. Parker and Prof. F. H. Garner, and on September 5 Sir Alfred Egerton will deliver a concluding lecture on "Civilization and the Use of Energy". Films are being shown daily while the exhibition is open.

The exhibition has been extremely well planned, and the exhibits are displayed effectively against a modern background which by its simplicity does nothing to distract the attention. The organisers are to be congratulated upon the arrangements adopted, and the exhibition deserves to be well attended.

A separate exhibition dealing with oil fuels is being shown to members of the Association in the University's Chemical Engineering Department.

\section{NEWS and VIEWS}

Civil Engineering at Birmingham : Prof. C. Batho

Prof. Cyril Batho, who retires in September, has occupied the chair of civil engineering in the University of Birmingham since 1924. Educated at the University of Liverpool, he later studied at Berlin and Charlottenburg and in 1908 was appointed lecturer in civil engineering, and in 1911 assistant professor, at MeGill University. During 1912-13 he acted as design engineer on the New Quebec Bridge, and in the following years published a number of papers on the stresses in structural members and connexions. After a period at the Royal Aircraft Establishment during the First World War, he became for a short time a lecturer at Trinity College, Cambridge, and in 1919 was appointed associate professor of applied mechanics and hydraulics at McGill University, where he remained until 1924. Prof. Batho was chairman of the Midland Association of Civil Engineers during 1932-34. As a member of the Steel Structures Research Committee he was responsible for a series of important investigations, the results of which appeared in reports of the Committee published in 1931, 1934 and 1936. He served also on a committee of the Institution of Civil Engineers which reported in 1938 on concrete containers for the storage of liquids, and, for a number of years, was engaged in research on reinforced concrete structures, a subject on which he published several papers. Since the termination of the Second World War he has directed a series of investigations supported by the Aluminium Development Association and related to the design of large structures in light alloys. Although Prof. Batho's main interests were coneerned with statically indeterminate structures and with riveted and other connexions, his work has covered a range of subjects, including creep in concrete and torsional stresses in thin-walled prisms. He has also wide interests in music, literature and the arts, which have led him on numerous journeys to Continental centres. His excellent lectures, illumined by a ready humour, will remain long in the memories of his students, and his colleagues will miss his wise and single-minded counsel in faculty and senate.

\section{Dr. S. C. Redshaw}

Dr. S. C. Redshaw, who has been appointed to succeed Prof. Batho, graduated at University College, Cardiff, in 1927 and took his Ph.D. in 1936. During
1927-32 he held posts in the aircraft industry. From 1933 until 1936 he was assistant lecturer in civil engineering at the City and Guilds College, Imperial College of Science and Technology, and acted as consultant to the British Aeroplane Co. In collaboration with Prof. A. J. S. Pippard he carried out research for Vickers (Aviation), Ltd., on geodetic construction. During 1936-40 he was scientific officer at the Building Research Station, where he specialized on research into the strength of bridges. In 1940 he was appointed chief airworthiness engineer and in 1945 chief engineer of Boulton Paul Aircraft, Ltd. In 1948 he became a director. As chief engineer he was responsible for all the technical work of the Company and for control of the design staff. His work has consisted of research and development in connexion with experimental methods of stress analysis, including model structural analysis, photoelastic and electrical analogue methods. The development of electronic methods of strain gauge measurements and the design of instruments for the automatic recording of strains and deflexions in flight also came under him. He is a member of the Mechanies Com. mittee of the Aeronautical Research Council and of the Technical Board of the Society of British Aircraft Constructors. $\mathrm{He}$ is also president of the Birmingham branch of the Royal Aeronautical Society and vicepresident of the Wolverhampton Engineering Society.

\section{Botany at the British Museum (Natural History): Dr. J. Ramsbottom, O.B.E.}

After almost forty years' service, the last twenty as keeper of botany, Dr. J. Ramsbottom will retire from the British Museum (Natural History) in October. In this key position he has had a profound and beneficent influence on British botany. On going to the Museum he specialized in fungi and soon became one of the foremost mycologists with a special interest in the larger fungi. During his keepership he became interested in a number of learned societies and more especially in the British Mycological Society, one of the friendliest groups of biologists that has ever existed, which owes much of its intimate character to his influence. Outside Great Britain he has done much to foster international understanding by his active friendship with mycologists all over the world. Dr. Ramsbottom has always insisted on the importance of broadly based taxonomy, and his own taxonomic interests have extended 